\title{
MUTUALIZING EURO AREA DEBT WITHOUT A FISCAL UNION
}

\section{Stefan Krause Montalbert ${ }^{1}$}

Recibido: 11/10/2017

Aprobado: 05/10/2018

\begin{abstract}
Several years have passed since the onset of the most recent financial crisis, and Europe is still not "off the hook." A twin crisis emerged: the sovereign debt crisis. The main objective of this paper is to design a mechanism for pooling Euro Area debt together, in order to lower short-term interest rates, and limit the risk of contagion. This design, which draws from existing proposals for jointly issued bonds in the Euro Area, contains features that would make it acceptable for participants (such as no ex-ante fiscal transfers across countries, and widespread benefits from lower debt-service payments), while placing a reasonable cap on potential losses from default by other participants through limited liability.
\end{abstract}

KEYWORDS: EURO AREA; SOVEREIGN DEBT CRISIS; MONETARY POLICY; EUROBONDS. JEL CLASIFICATION: E58, E62, F45, H63.

RESUMEN

Varios años han pasado desde el inicio de la crisis financiera más reciente, $y$ en Europa todavía no ha surgido una recuperación económica sostenible. Los niveles de desempleo permanecen altos en varios países y varias asimetrías se han agudizado; entre ellas, el diferencial que sobresale en los niveles de tasas de interés es consecuencia de una crisis "derivada": La crisis de la deuda soberana. El objetivo principal de este artículo es diseñar un mecanismo para la puesta en común de la deuda de la zona euro en conjunto, con el fin de reducir las tasas de interés a corto plazo, y limitar el riesgo de contagio. Este diseño, que se basa en las propuestas existentes para emitir bonos en forma conjunta en la zona del euro, contiene características que hacen que sea aceptable para los participantes (por ejemplo, no hay transferencias fiscales ex-ante en todos los países, y existen amplios beneficios de los pagos de servicio de deuda más bajos), mientras que conlleva a la colocación de un techo razonable a las posibles pérdidas por incumplimiento por parte de otros participantes a través de responsabilidad limitada.

PALABRAS CLAVE: ZONA EURO, DEUDA SOBERANA, POLÍTICA MONETARIA, EURO-BONOS. CLASIFICACIÓN JEL: E58, E62, F45, H63.

1 Universidad Latinoamericana de Ciencia y Tecnología (ULACIT), Facultad de Ciencias Empresariales; Código Postal 10235-1000; San José, Costa Rica; skrause@ulacit.ac.cr 


\section{INTRODUCTION}

Policymakers across the globe responded to the most recent financial crisis and ensuing worldwide recession with a policy mix designed to better withstand the potentially nefarious effects expected by experts and markets alike. This series of unprecedented phenomena since WWII resulted in a combination of active fiscal policy and accommodative monetary policy (Reinhart \& Rogoff, 2010). Yet, a twin crisis soon emerged in the Euro Area: the sovereign debt crisis. It entailed substantive risks to the monetary union, partly due to commitment and coordination issues, and also to heterogeneities across countries.

For starters, Greece had a debt-to-GDP ratio which had been growing long before the onset of the financial crisis, which made it a special case. Ireland was disproportionally hit by the financial crisis on account of its large exposure to the American and British banking systems. Furthermore, other countries (notably Italy, Portugal, Slovenia and Spain) were also paying high premia for their sovereign bonds, especially between 2011 and 2012. While the short-term interest rate spikes during this period may have been partly explained by rising public debts in each individual country, much of the volatility was the result of fears of contagion among some Euro Area countries, as well as a general rise in uncertainty with regards to the future of the common currency.

While at the time of writing, most interest rates on sovereign debt had decreased to more reasonable levels - mainly as a result of the actions undertaken by the European Central Bank (ECB) and the fiscal programs established in each country - a return to a period of increased uncertainty and contagion fears is not completely out of the question (Ehrmann \& Fratzcher, 2015). With this in mind, the main objective of this paper is to design a mechanism that "pools" Euro Area debt together, in order to lower short-term interest rates, and limits the risk of contagion. This design - which draws from existing proposals for jointly issued bonds in the Euro Area - contains features that would make it acceptable for participants (such as no ex-ante fiscal transfers across countries, and widespread benefits from lower debt-service payments), while placing a reasonable cap on potential losses from default by other participants through limited liability.

The remainder of the paper is organized as follows: Section 2 provides an overview of the European sovereign debt crisis and the subsequent response in the Euro Area. Section 3 describes the four main proposals for issuing joint Euro Area debt instruments, which were circulated between May 2011 and January 2012. Section 4 introduces a new proposal for jointly issued bonds that does not require the need for a fiscal union in the Euro Area, or any ex-ante net transfers between participating countries. Section 5 further studies this proposal and how the fund could evolve over time. Section 6 provides some conclusions and further extensions.

\section{THE EURO AREA SOVEREIGN DEBT CRISIS: SOME STYLIZED FACTS}

\subsection{Key facts and posible spiraling effects}

As of 2015, there are 19 sovereign country members in the Euro Area. Interestingly enough, at the end of 2013, only six of them (Estonia, Finland, Latvia, Lithuania, Luxembourg, and Slovakia) would have been in compliance with the "below 60\% debt-to-GDP ratio" rule set by the Stability and Growth Pact, as depicted in Appendix Figure 1. Furthermore, almost all New Member Countries - with the exceptions of Hungary (77\%) and Croatia (66\%) - were maintaining debt-to-GDP ratios below the $60 \%$ threshold (see Appendix Figure 2).

Nevertheless, the documented fiscal imbalances did not directly translated into price pressures. Since the mid-2008 inflation in the Euro Area has hovered around and below 2\% on average, while inflation expectations have remained firmly anchored. In recent years, despite record-low 
policy rates, deflation has been more of a concern. Furthermore, there exists evidence of a disconnect between fiscal sustainability and the level of the debt-GDP ratio (Polito \& Wickens, 2011), which may help explain why Spain and Slovenia (for example) had been paying higher interest rates on their newly-issued debt in 2011, despite having a lower debt-to-GDP ratio in comparison to countries like France and Germany.

At the end of 2011, interest rate differentials between countries of the Euro Area reached record levels since the inception of the Euro in many cases: For Portugal, the yield surpassed 13\%; while for Ireland, Italy, Slovenia and Spain rates were on average at levels between $6 \%-9 \%$. This at a time when the ECB main refinancing rate had been persistently near the $1 \%$ level. Even Belgium and Austria were paying relatively high premia on their newly issued debt, hovering around 3.5\%$5 \%$ yields.

\subsection{Euro area responses and aftermath}

In order to re-establish the proper functioning of the monetary transmission mechanism, the ECB began open market purchases of government and private debt securities in May 2010 (European Central Bank, ECB, 2010). This program was expanded in September 2012 with additional financial support in the form of selected yield-lowering bond purchases, through the Outright Monetary Transactions program (Draghi \& Constâncio, 2012). Another key measure was implemented in December 2011 with the introduction of Long Term Refinancing Operations, through which ECB loans supplemented inter-bank lending (Draghi \& Constâncio, 2011).

From the fiscal perspective, in January 2011 the European Council created the European Financial Stability Facility, an emergency funding program guaranteed by the European Commission using the budget of the European Union as collateral, which was replaced by the European Stability Mechanism (ESM) between September and October 2012 (European Commission, 2018). Also, on December 9th, 2011, the Euro Area Heads of State or Government issued a joint statement in which they indicated their willingness to establish new fiscal rules and reinforce existing ones(European Council, 2011).

Finally, individual countries adopted fiscal austerity plans to different degrees. In the particular situation of Greece, the Public Debt Relief Programme attributable to the debt restructuring in 2012 represented over 50\% of GDP. Estimates suggest that the present value haircut of the Greek debt exchange ended up in the range of 59-65 percent (Zettelmeyer, Trebesch \& Gulati, 2013). This parameter will be useful for the calibration exercises performed in Sections 4 and 5 .

\section{POTENTIAL EURO AREA RESPONSE TO THE CRISIS: PROPOSAL FOR JOINTLY ISSUED BONDS}

While the return to high interest rate differentials across countries constitutes (as of February 2015) at most a latent concern, the increased speculation over the future of the Euro Area over the past 6 -to- 9 months, coupled with recent developments in Greece, provides fertile ground for examining additional options. In this spirit, this paper revisits several proposals for issuing joint Euro Area bonds. I focus specifically on four such proposals that were circulated between May 2011 and January 2012:

I. The Blue Bond proposal, originally published by Jacques Delpla and Jakob von Weizsäcker in May 2010 (Depla \& Weizsäker, 2010). 
II. The European Redemption Pact, originally published by the German Council of Economic Experts in November 2011, with a 25 January 2012 addendum (German Council of Economic Experts, 2011).

III. The Stability Bonds, published by the European Commission on 23 November 2011 (European Commission, 2011).

IV. Eurobills, published by Christian Hellwig and Thomas Philippon on 2 December 2011 (Hellwig, \& Philippon, 2011).

The common objectives of these and other proposals were, in the short term, to "pool" Euro Area debt together, in order to lower short-term interest rates of countries paying a high premium (Italy, Spain, Portugal, others). In the long term, jointly issued bonds could lead up to creating a liquid market for Euro Area debt instruments, which could aid towards preventing future crises. Over the next few subsections I briefly describe the features of each of the plans, as well as some considerations for the design of Euro Area-wide bonds.

\subsection{The blue bond proposal}

The main idea put forth by Delpla and von Weizsäcker (2010) was for Euro Area governments to pool up to $60 \%$ of their sovereign debt "in the form of a common European government bond." These supra-national debt instruments, named Blue Bonds, would be jointly issued through a Euro Area-wide agency: The Independent Stability Council (ISC). The ISC would be in charge of the allocation of said bonds under the approval of the participating countries' parliaments.

Any government debt surpassing the $60 \%$ ceiling would continue to be issued by individual countries in the form of Red Bonds. While Blue Bonds, through their senior status and joint and several (JS) issuance, may become eligible to ECB refinancing operations, the junior Red Bonds without JS issuance would continue return to being ineligible for monetary open market operations. Finally, Blue Bonds would correspond to the operational equivalent of plain national sovereign debt, which is why tax revenues would be required to be transferred directly to the ISC.

\subsection{European redemption pact}

According to the German Council of Economic Experts (2011), the ECB had been "damaging its reputation [by continuing] its programme of buying Italian and Spanish debt." Furthermore, they claim that this constitutes a "blur" of the line that separates fiscal and monetary policy. The interventions in the sovereign debt market were thus "jeopardizing the credibility" of the ECB and the Eurosystem as a whole.

The European Redemption Pact proposal set forth by the Council, in a way, is by the design the exact opposite to the Blue Bond / Red Bond proposal: while individual countries would continue to issue sovereign debt instruments for up to $60 \%$ of their GDP, all national debt surpassing that ceiling would become part of a Redemption Fund. Said fund would be temporary by design, with the objective that any excess debt is paid off over a period of 20-to-25 years, via a debt-reduction plan adhered by all participating countries.

\subsection{Green paper on the feasibility of introducing stability bonds}

The European Commission (2011) suggested several plans for issuing Stability Bonds. The three approaches set forth in the document are: 1. Full substitution of national debt issuance with JS guarantees; 2. Partial substitution of national issuance with JS guarantees; 3. Partial substitution with several, but not joint guarantees. 
The Stability Bonds proposed under the first option are the closest to a concept of Eurobonds; meanwhile, the second option is equivalent to the Blue Bond / Red Bond proposal. Issuance of Stability Bonds could be centralized in a single agency or remain decentralized at the national level with tight co-ordination among the Member States. The introduction of commonly issued Stability Bonds would mean pooling sovereign issuance among Member States and sharing associated revenue flows and debt-servicing costs.

As in the case of Blue Bonds and the Redemption Fund, Stability Bonds would alter the existing structure of the EA sovereign bond market. The JS type of guarantee of the common bonds over the entire Euro Area debt would avoid potential runs on junior sovereign bonds. Also, the relative simplicity of Stability Bonds would make the arrangement less prone to "opacity" premiums associated with other plans.

\subsection{Eurobills}

Hellwig and Philippon (2011) offered an alternative to Eurobonds: to replace existing shortterm debt of Euro Area member countries through Eurobills. Their proposal would create a highly liquid market for European short-term debt, while allowing countries to maintain the right to issue longer-term debt (maturities over 1 year).

The plan includes creating a joint debt management office that would issue Eurobills (for up to $10 \%$ of the Euro Area GDP), as a Euro Area-wide short-term debt instrument with JS guarantees. As a result of the size and time-to-maturity of the common issuance, Eurobills would also alter the existing structure of the Euro Area sovereign bond market, but to a lesser extent than Blue Bonds, Eurobonds or the Redemption Fund.

\subsection{Considerations for the design of euro area-wide bonds}

To further assess the relative merits of the four above-described proposals, I briefly look at three evaluation criteria: constitutionality and time for implementation; projected size and moral hazard considerations; and expected impact on interest rates across the Euro Area.

\section{Implementation Considerations:}

Article 125 of the Treaty explicitly prohibits Member States from assuming liabilities of another Member State. Whereas Blue Bonds and Eurobonds would likely require to amend the Treaty, Eurobills may likely be implemented via an International Treaty. The Redemption Fund would rank somewhere in the middle, since not all Euro Area countries would participate. Still, in the end the JS guarantees would require in all four proposals the presence of ex-ante fiscal transfers, countering in one form or another Article 125.

Eurobills also hold the edge in terms of how rapidly they could be implemented. The Redemption Fund may take several years to be established, while the partial-to-full conversion of national debt into Euro Area-wide instruments could take significantly longer. Nevertheless, one can expect the announcement of any arrangement to have immediate effects on yields, which is part of the desired effect. 


\section{Size and Moral Hazard Considerations}

By design, Eurobills would entail the smallest Euro Area joint-issuance of financial instruments. Based on 2013 data, the size of the fund ${ }^{1}$ would be 973 billion Euro. With full JS guarantees, individual countries' liabilities in case of default by any one of the participating nations would be limited by their participation. For example, in the worse-case scenario of an Italy default (without haircut), the expected loss for the largest participant in the fund (Germany) would equal 46.7 billion Euro; while for the second- largest participant (France) it would amount to 35.2 billion Euro.

The expected size of the Redemption Fund would be roughly 3 trillion Euro. A default by Italy would represent a maximum liability for the largest remaining participant (France) of 239.9 billion Euro and, for the next-largest (Germany), 168.4 billion Euro. Blue Bonds would in theory represent a common fund of approximately 5.8 trillion Euro, meaning that an Italian default would cost the two largest participants (Germany and France) 280.4 billion and 211.0 billion Euro in losses, respectively. Finally, the largest Euro Area-wide issuance of bonds, Eurobonds, would amount to 8.8 trillion Euro. If Italy were to default on their debt, the expected liability to the two largest participants (again, Germany and France) would exceed 500 billion and 450 billion Euro, respectively.

While size- and moral hazard considerations are directly correlated, what separates the Redemption Fund from all other proposals is that only countries whose debt-to-GDP per capita exceeds the 60\% ceiling (and hence, are in violation of the Growth and Stability Pact) are liable, and their exposure is limited to their excess. Therefore, it works like a "club" in which its "bestbehaved" members have all the right incentives to leave, providing incentives for others to reduce their participation as well.

\section{Predicted impact on interest rates}

As mentioned at the beginning of this section, the goal of "pooling" Euro Area debt together, particularly in lieu of the events of 2010-2012, is to lower short-term interest rates of countries paying a high premium, and, over time, to create a liquid market for Euro Area debt instruments. Using national accounts data for 2013 and interest rates on government debt for the largest 10 Euro Area countries, I simulate interest rate scenarios for the different proposals, under comparable conditions. $^{2}$ The main results are as follows:

I. The Blue Bonds common interest rate results in significant reductions of both shortterm and long-term yields for countries with high interest rates (Portugal, Ireland, Italy and Spain), ranging between -160 and -370bps. Germany, Finland, Netherlands and Austria would see their average yields increase by 20 to 70 bps; while France and Belgium would not experience a significant change. Meanwhile, yields on Red Bonds either remain relatively unchanged or moderately increase for all countries, as expected.

II. For countries participating in the Redemption Fund, only Germany would suffer a moderate increase ranging from 30 to $60 \mathrm{bps}$ in their yields. Austria, Belgium, France and the Netherlands would see their interest rates relatively unchanged; while Portugal, Ireland,

1 For the following computations, I use Eurostat data for 16 Euro Area countries: Austria, Belgium, Estonia, Finland, France, Germany, Ireland, Italy, Latvia, Lithuania, Luxembourg, Netherlands, Portugal, Slovenia, Slovakia and Spain. Greece is excluded consistent with their debt-restructuring agreement in 2012, while Cyprus and Malta are left out as a result of data considerations.

2 Further results for these simulations are available upon request. 
Italy and Spain would experience sizeable reductions ranging from -100 to $-340 \mathrm{bps}$. The assumption is that, since Finland does not participate in the fund, there should not be any effect their yields; note however that I am not considering how the constitution of the fund and the (voluntary) exclusion of some countries could affect the market's perception of debt in those countries.

III. For Eurobonds the difference in effects is - as is to be expected - the largest: short- and long-term yield reductions for countries with high interest rates are similar to those from Blue Bonds (without the perverse effect on Red Bonds, by definition). However, low interest countries do experience larger increases in their yields: over 80 bps for both Finland and Germany, and between 20 and 50 bps for France, Austria and the Netherlands.

IV. Finally, Eurobills lead to a moderate decrease in short-term debt yields for Italy, Spain, Portugal and Ireland ranging between -40 and $-90 \mathrm{bps}$; and a small increase (10-20 bps) for Finland, Germany and the Netherlands. No perceptible impact is found for other countries, or for long-term bonds in all countries.

\section{CAN EURO AREA DEBT BE MUTUALIZED WITHOUT EX-ANTE FISCAL TRANSFERS?}

The proposals described in Section 3, with all their merits, have frequently encountered opposition. For large size funds like Eurobonds and Blue Bonds, the moral hazard risks are clearly magnified by the JS nature of the liability. Even a medium-size fund with selective participation like the European Redemption Fund "implies a significant transfer of sovereignty during the lifetime of the [Fund].”( (European Commission, Conclusion 10, 2014). Eurobills, on the other hand, while creating lower risks of moral hazard, could very well lead to increased uncertainty, and "overreliance of short-term debt in times of market volatility." (European Commission, Conclusion 23, 2014). And all options, as stated earlier, would require ex-ante fiscal transfers - to a smaller or larger extent - and therefore changes to the Treaty.

Is it possible then to come up with an arrangement that - while not completely eliminating moral hazard risks - may provide an "acceptable" level of liability? Would it still be feasible to reap the benefits of lower yields for countries whose sovereign debt may be exposed to speculative attacks, such as the ones in 2010-2012 ${ }^{3}$ Could this arrangement have the right set of incentives for participants, while preserving conditions intact for non-participants? And finally, Can it be implemented without the need - at the very least - of ex-ante fiscal transfers across countries, preserving the trend towards increased economic integration, without the need (at this time) for further political integration? (Brou \& Ruta, 2011) The current section looks into the theoretical design of such an arrangement.

\subsection{The present-day "excess debt club" (2013-2015)}

The arrangement proposed draws heavily from the European Redemption Pact, with some notable exceptions and modifications. Based on the principle that participation would only be compulsory for countries whose present debt levels exceed 60\% of GDP, I will hereon forth refer to it as the "Excess Debt Club" (EDC, for short).

3 A recent proposal of European Safe Bonds (ESBIES), put forward by Brunnermeier, Langfield, Pagano, Reis, Van Nieuwerburgh and Vayanos (2016), conducts an analysis as to how the joint issuance of Euro Area bonds would lower yields to at most the levels of the German Bunds. 
The EDC inherits by design the same features of the Redemption Fund. However, it has been modified to allow for the participation of Ireland and Portugal. Also, the EDC does not hinge upon the existence of a debt-repayment structured plan by its participants, nor does it "lock" participation for a pre-specified period of time (i.e., countries may leave the EDC at any time, provided they have reduced their debt-to-GDP ratio below 60\%).

Other differences between the EDC and the Redemption Fund involve elements drawn from other proposals. Consistent with the institutional setup of Blue Bonds, the distribution of payments between member states will be calibrated in such a way that ensures countries' participation. To avoid the problems associated with individual country's issuing their own debt (nonparticipants, and up to $60 \%$ of GDP for participants), EDC bonds will have a junior status to all other sovereign debt - which implies that bond-holders should price-in a sizeable enough "haircut" in case of default. And finally, in the spirit of the Eurobills proposal, the EDC would issue relatively short-term debt instruments (i.e., not exceeding 5 years to maturity).

The main distinguishing feature is that EDC members will have several, but only limited liability. This implies that each sovereign debtor would guarantee:

- Payment of principal and interest up to a fixed percentage that would be expressly indicated in the bond [individual shares to be determined].

- In case of default by one or more sovereign debtors, partial payment of the share of those who defaulted [share to be determined].

\subsection{Definitions and set-up}

\section{Exogenous variables}

- $\quad$ Let $\alpha$ be the partners' share of liability (common to all participants); .

- $\quad$ Let $\beta_{\mathrm{i}}$ be the relative share in the $\mathrm{EDC}$ (specific to each participant); .

- Let $\theta$ be the haircut expected by bond-holders in case of default (common to all participants);

- Let $\rho$ be the correlation between default probabilities (common to all participants); .

- Let $r_{i}$ be the country's own interest rate (specific to each participant).

- Let $r$ be the risk-free interest rate (common to all participants).

- $\quad$ Let $\lambda$ be the liquidity premium (common to all participants).

\section{Endogenous variables}

Let $\gamma_{i}$ be the recovery fraction of a one-Euro investment in case of default (specific to each participant):

$$
\gamma_{i}=(1-\theta)\left[(1-\rho) \alpha / \beta_{i} \sum_{(J \neq i)}{ }^{\wedge} n\left(1-\delta_{j}\right) \quad \beta_{j}+(1-\alpha)\right]
$$

where $\delta_{i}$ is the probability of default (specific to each participant) given by:

$$
\delta_{i}=\left(r_{i}-r\right) /\left(\sum_{(j=1)}{ }^{n} \beta_{j} Y_{j}\right)
$$



obtained:

The price of a one Euro discount bond common for all EDC participants would be thusly

$$
P_{N B C}=\sum_{(i=1)}^{n} \beta_{i}\left[\left(1-\delta_{i}\right)+\delta_{i} y_{i}\right]
$$

which implies that the resulting common interest rate for the EDC bonds would equal:

Alternatively, we can define the country-specific yield each EDC participant would pay as:

$$
\delta_{i}=r_{i}\left(r_{E D C} / r_{A V G}\right)
$$

Where the weighted average of the interest rate, is given by:

$$
r_{A V G}=1 / n \sum_{(i=1)}^{n} \beta_{i} r_{i}
$$

Country-specific yields for the EDC imply that each government makes yearly payments on its participation in the fund, relative to the national interest rates used to compute the average rate (De Grauwe \& Moesen, 2009).

\subsection{Data, calibration and scenarios}

\section{Assumptions}

A.Investors (bond-holders) are risk-neutral

B.No moral hazard behavior regarding deficits and debt by participating countries

\section{Baseline Scenario}

- $\alpha=50 \%$ (limited liability)

- $\theta=33.3 \%$ (in Greece's debt restructuring, the haircut was above 50\%)

- $\rho=0.1$ (relatively low risk of contagion)

- $r=1.50 \%$ (interest rates on short-term German Bunds at the end of 2011)

- $\lambda=30$ bps (Delpla and von Weizsäcker, 2010)

Based on the national accounts data, ten countries would participate in the initial EDC starting 2015 (EDC-10). The baseline scenario excludes Greece at the present time, as well as Cyprus and Malta for data considerations. The remaining six Euro Area countries (Estonia, Finland, Latvia, Lithuania, Luxembourg, and Slovakia) as of 2013 have debt-to-GDP ratios below the 60\% rule set up by the Stability and Growth Pact, and hence would not need to "join the club."

The data on country-specific variables is obtained form Eurostat and it is based on prevailing interest rates during the fourth quarter of 2011; and participation in the EDC based on national accounts data from 2013. The summary information is presented in the following table: 
TABLE 1

COUNTRY INTEREST RATES, DEBT-TO-GDP RATIO AND PARTICIPATION IN EDC (2015)

\begin{tabular}{|c|c|c|c|c|}
\hline \multirow[b]{2}{*}{ Country } & \multirow{2}{*}{$\begin{array}{c}\text { 2011:QIV } \\
\text { own r } \\
\%\end{array}$} & \multirow{2}{*}{$\begin{array}{c}2013 \\
\begin{array}{c}\text { Debt/GDP } \\
\%\end{array}\end{array}$} & \multicolumn{2}{|c|}{ Participation in EDC } \\
\hline & & & $\%$ & $\begin{array}{c}\text { in billions } \\
€\end{array}$ \\
\hline Austria & 3,30 & 72,3 & 0,92 & 28,74 \\
\hline Belgium & 4,80 & 97,9 & 4,70 & 146,93 \\
\hline France & 3,00 & 91,1 & 19,14 & 598,51 \\
\hline Germany & 2,00 & 76,4 & 11,27 & 352,56 \\
\hline Ireland & 8,50 & 116,1 & 3,64 & 113,82 \\
\hline Italy & 7,20 & 127,8 & 44,87 & $1.403,26$ \\
\hline Netherlands & 2,40 & 68,9 & 1,26 & 39,49 \\
\hline Portugal & 13,00 & 124,8 & 4,42 & 138,38 \\
\hline Slovenia & 6,90 & 70,0 & 0,08 & 2,54 \\
\hline Spain & 6,20 & 91,6 & 9,70 & 303,23 \\
\hline
\end{tabular}

Source: Own computations, based on data by Eurostat

\section{Alternative Scenarios}

- Alternative Scenario 1: Higher contagion $(\rho=0.3)$ and lower liquidity premium ( $\lambda=10 \mathrm{bps})$.

- Alternative Scenario 2: Full joint liability $(a=100 \%)$

- Alternative Scenario 3: Baseline Scenario is replicated assuming each EDC-10 member pays a specific interest rate, based on their own rates.

TABLE 2.1

BASELINE SCENARIO (2015):COMMON INTEREST RATE

$(A=50 \% ; P=0.1 ; \Lambda=30$ BPS $)$

\begin{tabular}{lccrrr}
\hline \multicolumn{1}{c}{ Country } & $\begin{array}{c}2011: \mathrm{Q} 4 \\
\text { own } \mathrm{r} \\
\%\end{array}$ & $\begin{array}{c}\text { EDC-10 } \\
\text { common } \mathrm{r} \\
\%\end{array}$ & $\begin{array}{c}\text { Prob. of default } \\
\%\end{array}$ & $\begin{array}{c}\text { Expected gains in } \\
\text { billions (no def.) } \\
€\end{array}$ & $\begin{array}{c}\text { Expected gains in } \\
\text { billions (with def.) } \\
€\end{array}$ \\
\hline Austria & 3,30 & 2,78 & 2,40 & 0,15 & $(0,91)$ \\
Belgium & 4,80 & 2,78 & 4,50 & 2,97 & $(3,31)$ \\
France & 3,00 & 2,78 & 2,60 & 1,32 & $(20,04)$ \\
Germany & 2,00 & 2,78 & 0,70 & $(2,75)$ & $(13,90)$ \\
Ireland & 8,50 & 2,78 & 9,50 & 6,51 & $(0,04)$ \\
Italy & 7,20 & 2,78 & 7,60 & 62,02 & 14,65 \\
Netherlands & 2,40 & 2,78 & 1,20 & $(0,15)$ & $(1,47)$ \\
Portugal & 13,00 & 2,78 & 15,60 & 14,14 & 3,75 \\
Slovenia & 6,90 & 2,78 & 7,30 & 0,10 & $(0,03)$ \\
Spain & 6,20 & 2,78 & 6,40 & 10,37 & $(3,90)$ \\
\hline EDC-10 & \multicolumn{7}{c}{} & 94,69 & $(25,19)$ \\
\hline
\end{tabular}

Source: Own computations, based on data by Eurostat 
The Baseline Scenario suggests that only two countries (Germany and the Netherlands) would incur into higher borrowing costs for the portion of their debt financed through EDC-bonds. The expected losses (and therefore ex-ante transfers) would be relatively low: 2.75 billion Euro for Germany and 150 million Euro for the Netherlands, annually. Meanwhile, Italy (the largest participant in the fund with near 45\%) is the country with most to gain from membership, as their annual interest payments would be lowered by 62 billion Euro. The net gains stemming from a common interest rate for all countries in the EDC-10 would add to almost 95 billion Euro.

Factoring into the costs of membership the implicit country-specific default probabilities and the resulting correlation from contagion, the total expected loss from default in a given year would amount to almost 120 billion Euro for all EDC-10 members. Therefore, the gains from lower average interest payments would partially offset the expected cost of default. Once the expected costs of a default are considered, Italy - and to some extent Portugal - continue to benefit from this arrangement. Expected net losses for most countries would be relatively low-to-moderate, with the exceptions of France (20 billion Euro net loss) and Germany (nearly 14 billion Euro net loss).

TABLE 2.2

ALTERNATIVE SCENARIO \#1 (2015):

COMMON INTEREST RATE

$(A=50 \% ; P=0.3 \wedge=10$ BPS $)$

\begin{tabular}{lrrrrr}
\hline Country & $\begin{array}{c}2011: \mathrm{Q} 4 \\
\text { own r } \\
\%\end{array}$ & $\begin{array}{c}\text { EDC-10 } \\
\text { common r } \\
\%\end{array}$ & $\begin{array}{c}\text { Prob. of } \\
\text { default } \\
\%\end{array}$ & $\begin{array}{c}\text { Expected gains in } \\
\text { billions (no def.) } \\
€\end{array}$ & $\begin{array}{c}\text { Expected gains in } \\
\text { billions (with def.) } \\
€\end{array}$ \\
\hline Austria & 3,30 & 3,42 & 2,60 & $(0,03)$ & $(1,17)$ \\
Belgium & 4,80 & 3,42 & 4,80 & 2,03 & $(4,66)$ \\
France & 3,00 & 3,42 & 2,80 & $(2,51)$ & $(25,30)$ \\
Germany & 2,00 & 3,42 & 0,70 & $(5,01)$ & $(16,85)$ \\
Ireland & 8,50 & 3,42 & 10,20 & 5,78 & $(1,20)$ \\
Italy & 7,20 & 3,42 & 8,10 & 53,04 & 2,60 \\
Netherlands & 2,40 & 3,42 & 1,30 & $(0,40)$ & $(1,81)$ \\
Portugal & 13,00 & 3,42 & 16,70 & 13,26 & 2,20 \\
Slovenia & 6,90 & 3,42 & 7,80 & 0,09 & $(0,05)$ \\
Spain & 6,20 & 3,42 & 6,80 & 8,43 & $(6,73)$ \\
\hline EDC-10 & & & & 74,67 & $(52,97)$ \\
\hline
\end{tabular}

Source: Own computations, based on data by Eurostat

A higher chance of contagion $(\rho=0.3)$ and a lower liquidity premium $(\lambda=10$ bps $)$ under Alternative Scenario \#1, would imply that - aside from Germany and the Netherlands - France (and to a much lesser extent, Austria) would now also incur into ex-ante expected transfers, resulting from a higher interest rate. Italy remains the main beneficiary of a common interest rate, as expected; meanwhile, the net gains for the EDC-10 in its entirety would come close to 75 billion Euro.

The increased correlation between individual countries' defaults rises the expected loss both directly and through the increment of the implicit individual default probabilities to near 128 billion Euro. As a result, the net losses for France and Germany also increase to 25 billion Euro and 17 billion Euro, respectively. Italy and Portugal remain the net beneficiaries after accounting for the expected losses from default, albeit with relatively small amounts (2.6 billion Euro and 2.2 billion Euro, respectively). 
TABLE 2.3

ALTERNATIVE SCENARIO \#2 (2015):

COMMON INTEREST RATE

$(A=100 \% ; P=0.1 ; \Lambda=30$ BPS $)$

\begin{tabular}{lrrrrr}
\hline Country & $\begin{array}{c}2011: \mathrm{Q} 4 \\
\text { own } \mathrm{r} \\
\%\end{array}$ & $\begin{array}{c}\text { EDC-10 } \\
\text { common } \mathrm{r} \\
\%\end{array}$ & $\begin{array}{c}\text { Prob. of default } \\
\%\end{array}$ & $\begin{array}{c}\text { Expected gains } \\
\text { in billions (no } \\
\text { def.) } \\
€\end{array}$ & $\begin{array}{c}\text { Expected gains in } \\
\text { billions (with def.) } \\
€\end{array}$ \\
\hline Austria & 3,30 & 2,24 & 2,20 & 0,30 & $(1,22)$ \\
Belgium & 4,80 & 2,24 & 4,10 & 3,76 & $(3,69)$ \\
France & 3,00 & 2,24 & 2,30 & 4,55 & $(25,02)$ \\
Germany & 2,00 & 2,24 & 0,60 & $(0,85)$ & $(19,66)$ \\
Ireland & 8,50 & 2,24 & 8,60 & 7,13 & 1,71 \\
Italy & 7,20 & 2,24 & 6,90 & 69,60 & 47,72 \\
Netherlands & 2,40 & 2,24 & 1,10 & 0,06 & $(2,05)$ \\
Portugal & 13,00 & 2,24 & 14,20 & 14,89 & 8,97 \\
Slovenia & 6,90 & 2,24 & 6,90 & 0,12 & $(0,01)$ \\
Spain & 6,20 & 2,24 & 6,20 & 12,01 & $(2,15)$ \\
\hline EDC-10 & & & & 111,57 & 4,62 \\
\hline
\end{tabular}

Source: Own computations, based on data by Eurostat

Turning now to the case with full-liability, while maintaining all other parameters as in the Baseline Scenario, Alternative Scenario \#2 confirms that the overall gains for the EDC-10 are higher than in the case of limited liability, given the further reduction of the common interest rate. Only Germany would experience a revenue loss of less than 1 billion Euro, while the remaining nine countries combined would reduce their interest payments by over 112 billion Euro per year.

Full liability also slightly reduces the probability of default (given our assumption of no moral hazard behavior by participating countries), yielding an expected loss from default of 107 billion Euro for all EDC-10 members. As expected, this agreement makes Italy considerably better off (a net gain of nearly 48 billion Euro) while France and Germany would carry the brunt of the cost (net losses of 25 billion Euro and 20 billion Euro, respectively). Finally, under these conditions, the overall net gain from lower interest payments for all EDC-10 members would slightly offset the expected loss from default.

The next set of results introduces the possibility that countries make yearly payments in direct proportion to the interest rates they pay on their own sovereign debt. 
TABLE 2.4

ALTERNATIVE SCENARIO \#3 (2015):

COUNTRY SPECIFIC INTEREST RATES

$(A=50 \% ; P=0.1 ; \Lambda=30$ BPS $)$

\begin{tabular}{lrrrrr}
\hline Country & $\begin{array}{c}2011: \mathrm{Q} 4 \\
\text { own } \mathrm{r} \\
\%\end{array}$ & $\begin{array}{c}\text { EDC-10 } \\
\text { common } \mathrm{r} \\
\%\end{array}$ & $\begin{array}{c}\text { Prob. of default } \\
\%\end{array}$ & $\begin{array}{c}\text { Expected gains } \\
\text { in billions (no } \\
\text { def.) } \\
€\end{array}$ & $\begin{array}{c}\text { Expected gains in } \\
\text { billions (with def.) } \\
€\end{array}$ \\
\hline Austria & 3,30 & 1,58 & 2,40 & 0,49 & $(0,57)$ \\
Belgium & 4,80 & 2,30 & 4,50 & 3,68 & $(2,60)$ \\
France & 3,00 & 1,44 & 2,60 & 9,36 & $(12,00)$ \\
Germany & 2,00 & 0,96 & 0,70 & 3,68 & $(7,48)$ \\
Ireland & 8,50 & 4,07 & 9,50 & 5,04 & $(1,50)$ \\
Italy & 7,20 & 3,45 & 7,60 & 52,67 & 5,30 \\
Netherlands & 2,40 & 1,15 & 1,20 & 0,49 & $(0,82)$ \\
Portugal & 13,00 & 6,22 & 15,60 & 9,38 & $(1,01)$ \\
Slovenia & 6,90 & 3,30 & 7,30 & 0,09 & $(0,04)$ \\
Spain & 6,20 & 2,97 & 6,40 & 9,80 & $(4,47)$ \\
\hline EDC-10 & & & & 94,69 & $(25,19)$ \\
\hline
\end{tabular}

Source: Own computations, based on data by Eurostat

Since the features of the EDC-10 bond for investors (compared to the Baseline Scenario) are unchanged, the implicit probabilities of default for each country, the net gains from the lower average common rate, and the expected costs from default for the aggregate of the EDC10 members will all remain the same as in the Baseline Scenario. The changes are present in the gains obtained by each individual country: by construction, all members benefit from lower interest payments. Furthermore, their gains are closer to being proportional in size to their respective participations in the fund - with added benefits for countries with high interest rates on their sovereign debt. Perhaps even more relevant is the fact that expected losses for France and Germany after taking into account the possibility of default have been cut nearly in half - compensated by a reduction of 10 billion Euro in the net expected gains for Italy.

Some general observations from our results are:

1. There are overall gains from "pooling" debt together, even with limited liability;

2. These overall gains could be large enough to compensate for expected losses in case of default for the full liability scenario;

3. Higher probability of contagion and lower liquidity premium result in only moderate reductions in the gains obtained from a lower average rate.

4. Although the full liability case leads to net gains, the resulting asymmetric gains and losses after accounting for expected default would likely make this arrangement difficult to implement.

5. Allowing for countries to pay in direct proportion to their own interest rates would significantly reduce the asymmetries in gains and losses, while preserving the overall benefit due to lower average interest rates. 


\subsection{Risk-Sharing under the "Excess Debt Club"}

The cost-benefit analysis from the previous subsection computes expected gains and losses from pooling debt for EDC-10 members. But what is the bottom line? How much would each country have to contribute for bailing out any one of its partners? The following table estimates the liability costs net of interest payment gains for the four largest economies of the Euro Area (which are also the four main participants in the EDC-10 fund). The computations are based on Alternative Scenario \#3, assuming a low probability of contagion $(\rho=0.1)$; a liquidity premium of $30 \mathrm{bps}$; limited liability $(\alpha=50 \%)$; and allowing each EDC-10 member to pay a specific interest rate, based on their own country rates.

TABLE 3

LIABILITY COSTS NET OF INTEREST PAYMENT GAINS FOR THE BIG FOUR (2015): COUNTRY SPECIFIC INTEREST RATES

$(A=50 \% ; P=0.1 ; \wedge=30$ BPS $)$

\begin{tabular}{lrrrr}
\hline \multicolumn{1}{c}{ Country } & $\begin{array}{c}\text { Net Liability Cost } \\
\text { if FRA defaults }\end{array}$ & $\begin{array}{r}\text { Net Liability Cost } \\
\text { if GER defaults }\end{array}$ & $\begin{array}{c}\text { Net Liability Cost } \\
\text { if ITA defaults }\end{array}$ & $\begin{array}{c}\text { Net Liability Cost } \\
\text { if SPA defaults }\end{array}$ \\
\hline France & 189,94 & 15,96 & 152,85 & 16,31 \\
Germany & 24,11 & 113,73 & 91,87 & 11,45 \\
Italy & 57,92 & 6,70 & 414,61 & 7,51 \\
Spain & 14,10 & 3,03 & 72,38 & 91,18 \\
Other EDC-10 & 17,85 & 0,70 & 108,17 & $(2,38)$ \\
\hline
\end{tabular}

Source: Own computations, based on data by Eurostat

Two key observations from this preferred arrangement:

1. For all four countries, the net cost of bailing-out any of their partners is always lower than the net cost they themselves would incur into in case of default;

2. Even in the worst-case scenario (i.e., an Italian default) net bail-out expenses are limited, and in all cases (except for France), considerably lower than their subscribed capital at the ESM in 2013. 


\section{THE “EXCESS DEBT CLUB” IN THE FUTURE (2023-2025)?}

The incentive mechanism provided through the design of the "Excess Debt Club" is not only confined to expected gains from lower interest rates and restricting potential losses in case of default. There is also an incentive to "leave the club", thereby eliminating any liability or forced participation in a partners' bail-out. In this Section I look at the composition of the EDC ten years into the future, while once more examining different scenarios for the remaining members.

\subsection{Calibration and scenarios}

\section{Additional assumptions}

C. Average nominal GDP growth of 1.5\% per year (common for all Euro Area countries)

D. Average nominal debt growth of $-1 \%$ per year (common for all Euro Area countries)

Based on the projections, there would be six countries participating in the EDC starting 2025 (EDC-6); with the assumed parameters, Austria, Germany, the Netherlands, and Slovenia would successfully reduce their debt-to-GDP ratios below $60 \%$ before the end of 2023, and therefore would drop out of the "Excess Debt Club" from thereonforth.

The country-specific variables (based again on prevailing interest rates during the fourth quarter of 2011; and participation in the EDC based on projections from national accounts data for 2023) are presented in the following table:

TABLE 4

COUNTRY INTEREST RATES, DEBT-TO-GDP RATIO AND PARTICIPATION IN EDC (2025)

\begin{tabular}{lrrrr}
\hline \multirow{2}{*}{ Country } & \multicolumn{1}{c}{$2011:$ QIV } & \multicolumn{2}{c}{ Participation in EDC } \\
\cline { 2 - 5 } & own $\mathrm{r}$ & Debt/GDP & \multicolumn{1}{c}{$\%$} & in billions \\
\hline Austria & 3,30 & 56,4 & out & - \\
Belgium & 4,80 & 76,3 & 4,70 & 57,18 \\
France & 3,00 & 71,0 & 15,72 & 191,22 \\
Germany & 2,00 & 59,6 & out & - \\
Ireland & 8,50 & 90,5 & 4,60 & 55,91 \\
Italy & 7,20 & 99,6 & 60,95 & 741,13 \\
Netherlands & 2,40 & 53,7 & out & - \\
Portugal & 13,00 & 97,2 & 5,92 & 71,94 \\
Slovenia & 6,90 & 54,6 & out & - \\
Spain & 6,20 & 71,4 & 8,11 & 98,65 \\
\hline
\end{tabular}

Source: Own computations, based on data by Eurostat 


\section{Alternative Scenarios}

For all scenarios I consider the case where each member of the EDC-6 pays a specific interest rate, based on the rates for their own debt. Also, for comparison purposes I leave some parameters from the Baseline Scenario of Section 4 unchanged (haircut $\theta=33.3 \%$; and risk-free rate $r$ $=1.50 \%$ ); while allowing for changes in the risk of contagion among remaining members $(\rho)$, the liquidity premium $(\lambda)$, and the extent of the joint liability (a):

- $\quad$ Alternative Scenario 4: Moderate contagion $(\rho=0.2)$ and liquidity premium $(\lambda=20 \mathrm{bps})$; $\alpha=50 \%$.

- $\quad$ Alternative Scenario 5: Higher contagion $(\rho=0.4)$ and no liquidity premium $(\lambda=0 \mathrm{bps})$; $\alpha=50 \%$.

- Alternative Scenario 6: Moderate contagion $(\rho=0.2)$ and liquidity premium $(\lambda=20 \mathrm{bps})$; $\alpha=100 \%$.

\subsection{Results}

TABLE 5.1

ALTERNATIVE SCENARIO \#4 (2025):

COUNTRY SPECIFIC INTEREST RATES

$(A=50 \% ; P=0.2 ; \Lambda=20$ BPS $)$

\begin{tabular}{|c|c|c|c|c|c|}
\hline Country & $\begin{array}{c}\text { 2011:Q4 } \\
\text { own r } \\
\%\end{array}$ & $\begin{array}{c}\text { EDC-10 } \\
\text { common r } \\
\%\end{array}$ & $\begin{array}{l}\text { Prob. of } \\
\text { default } \\
\%\end{array}$ & $\begin{array}{l}\text { Expected gains } \\
\text { in billions (no } \\
\text { def.) } \\
€\end{array}$ & $\begin{array}{c}\text { Expected gains } \\
\text { in billions } \\
\text { (with def.) } \\
€\end{array}$ \\
\hline Belgium & 4,80 & 2,57 & 4,7 & 1,28 & $(2,37)$ \\
\hline France & 3,00 & 1,61 & 2,7 & 2,67 & $(8,26)$ \\
\hline Ireland & 8,50 & 4,55 & 10,0 & 2,21 & $(2,15)$ \\
\hline Italy & 7,20 & 3,85 & 8,0 & 24,81 & $(1,40)$ \\
\hline Portugal & 13,00 & 6,96 & 16,4 & 4,35 & $(2,45)$ \\
\hline Spain & 6,20 & 3,32 & 6,7 & 2,84 & $(3,89)$ \\
\hline EDC- 6 & & & & 38,16 & $(20,51)$ \\
\hline
\end{tabular}

Source: Own computations, based on data by Eurostat

As with Alternative Scenario \#3 in Section 4, the country-specific interest rates imply lower borrowing costs for all EDC-6 participants, and therefore no ex-ante transfers. For five participants these gains are moderate (ranging between 1.3 billion Euro for Belgium and 4.4 billion Euro in the case of Portugal). Italy is once again the country with most to gain from membership (their share in the fund having increased from $45 \%$ to $61 \%$ ), as their annual interest payments would be lowered by nearly 25 billion Euro. The net gains stemming from lower interest rates for all countries in the EDC-6 aggregate would exceed 38 billion Euro.

Taking into account the implicit country-specific default probabilities and a moderate risk of contagion $(\rho=0.2)$, the total expected loss from default in a given year would amount to close to 59 billion Euro for all EDC- 6 members. Therefore, the gains from lower average interest payments would partially offset the expected cost of default. Expected net losses for most countries would be relatively low-to-moderate; the largest would be for France (approximately 8.3 billion Euro net loss). 
TABLE 5.2

ALTERNATIVE SCENARIO \#5 (2025): COUNTRY SPECIFIC INTEREST RATES

$(A=50 \% ; P=0.4 ; \Lambda=0$ BPS $)$

\begin{tabular}{|c|c|c|c|c|c|}
\hline Country & $\begin{array}{c}\text { 2011:Q4 } \\
\text { own } r \\
\%\end{array}$ & $\begin{array}{c}\text { EDC-6 } \\
\text { specific } r \\
\%\end{array}$ & $\begin{array}{l}\text { Prob. of } \\
\text { default } \\
\%\end{array}$ & $\begin{array}{c}\text { Expected gains in } \\
\text { billions (no def.) } \\
€\end{array}$ & $\begin{array}{l}\text { Expected gains in } \\
\text { billions (with def. } \\
€ \text { ) }\end{array}$ \\
\hline Belgium & 4,80 & 3,21 & 5,1 & 0,91 & $(3,04)$ \\
\hline France & 3,00 & 2,00 & 3,0 & 1,90 & $(10,00)$ \\
\hline Ireland & 8,50 & 5,68 & 10,9 & 1,58 & $(3,14)$ \\
\hline Italy & 7,20 & 4,81 & 8,7 & 17,70 & $(10,79)$ \\
\hline Portugal & $13,00 \%$ & $8,69 \%$ & $17,9 \%$ & 3,10 & $(4,25)$ \\
\hline Spain & $6,20 \%$ & $4,14 \%$ & $7,3 \%$ & 2,03 & $(5,27)$ \\
\hline EDC-6 & & & & 27,22 & $(36,49)$ \\
\hline
\end{tabular}

Source: Own computations, based on data by Eurostat

Alternative Scenario \#5 considers the case of both an increased correlation between defaults ( $\rho=0.4$; justified by the smaller number of participants and higher inherent risk), and the elimination of the liquidity premium (due to a smaller volume of debt issuance by the EDC- 6 in 2025 compared to the EDC-10 in 2015). Gains from paying lower interest rates decrease by around 11 billion Euro, but still remain positive for all members and quite sizeable in the case of Italy (17.7 billion Euro).

The higher contagion risk, and the slight increases in individual countries' implicit default probabilities, imply that total expected losses from default in a given year would increase to 64 billion Euro for all EDC-6 members. As before, the gains from lower average interest payments would partially offset the expected cost of default.

TABLE 5.3

ALTERNATIVE SCENARIO \#6 (2025): COUNTRY SPECIFIC INTEREST RATES $(A=100 \% ; P=0.2 ; \Lambda=20$ BPS $)$

\begin{tabular}{lrrrrr}
\hline Country & $\begin{array}{c}\text { 2011:Q4 } \\
\text { own r }\end{array}$ & $\begin{array}{r}\text { EDC-6 } \\
\text { specific } \text { r }\end{array}$ & $\begin{array}{c}\text { Prob. of } \\
\text { default }\end{array}$ & $\begin{array}{c}\text { Expected gains } \\
\text { in billions (no } \\
\text { def.) }\end{array}$ & $\begin{array}{c}\text { Expected gains } \\
\text { in billions } \\
\text { (with def.) }\end{array}$ \\
\hline Belgium & 4,80 & 2,30 & 4,5 & 1,43 & $(3,80)$ \\
France & 3,00 & 1,44 & 2,6 & 2,98 & $(14,52)$ \\
Ireland & 8,50 & 4,08 & 9,5 & 2,47 & $(2,29)$ \\
Italy & 7,20 & 3,46 & 7,6 & 27,74 & 15,33 \\
Portugal & 13,00 & 6,24 & 15,7 & 4,86 & $(0,64)$ \\
Spain & 6,20 & 2,98 & 6,4 & 3,18 & $(5,45)$ \\
\hline EDC-6 & & & & 27,22 & $(36,49)$ \\
\hline
\end{tabular}

Source: Own computations, based on data by Eurostat

Finally, Alternative Scenario \#6 looks at the case of full-liability. Just like in the analysis in Section 4, this is the scenario that leads to the largest gains from reduced servicing of the debt, and the lowest aggregate expected cost of default. Once more, however, it poses a large asymmetry in benefits and costs: while Italy experiences a net expected gain of over 15 billion Euro, France would carry an expected loss near equal to that amount.would partially offset the expected cost of default. 


\section{CONCLUSIONS AND POSSIBLE EXTENSIONS}

The "Excess Debt Club" design introduced in this paper, while drawing from existing proposals for jointly issued bonds in the Euro Area, does not require the need for a fiscal union; nor does it call - under the preferred option of country-specific interest payments - for ex-ante net transfers between participating countries. This design results in expected gains from lower interest rates for all participants, while placing a cap on potential losses in case of default through limited liability. Finally, it creates an incentive to "leave the club" - countries that reduce their-debt-to-GDP ratios below the $60 \%$ threshold would no longer be required to participate in the joint fund, thereby eliminating any liability for them if another country were to default on their sovereign debt. Given these features, and the fact that only Euro Area countries who are in violation of the Stability and Growth Pact would be obligated to join, it is likely that the proposal will not require changes in the European Treaty per se, but rather enforcement provisions for the Pact -to be potentially drawn in the form of an international treaty among participating nations.

Admittedly, this just constitutes a first step towards the design of the joint debt instrument. Further analysis on the particular features of the fund, the roll-over of national debt into jointlyissued debt, and specifics on how to draw the limited liability contract are a natural extension to further assess the feasibility of the proposal set forth in this paper. Also, additional scenarios and country-specific projections for debt and GDP-growth would provide more information on the relative costs versus benefits of the design.

Finally, while I have made an initial attempt on addressing the moral hazard concerns associated with Euro Area debt mutualization, further work is needed in order to study whether countries may have an incentive to run higher fiscal deficits and debts, as a result of the joint-liability, and specifics regarding the nature of a potential bail-out process by the liable parties. 


\section{REFERENCES}

Brou, D., \& Ruta, M. (2011). Economic Integration, Political Integration or Both? Journal of the European Economic Association, 9(6), 1143-1167. https://doi.org/10.1111/j.15424774.2011.01037.x

Brunnermeier, M. K., Langfield, S., Pagano, M., Reis, R., Van Nieuwerburgh, S., \& Vayanos, D. (2017). ESBies: safety in the tranches (ESRB Working Paper $\mathrm{N}^{\circ} 21$ ). Retrieved from https:// www.esrb.europa.eu/pub/task_force_safe_assets/html/index.en.html

De Grauwe, P. \& Moesen, W. (2009, April 3). Gains for All: A proposal for a common Eurobond. Retrieved from https://www.ceps.eu/publications/gains-all-proposal-common-eurobond

Delpla, J., \& von Weizsäcker J. (2010, May). The Blue Bond Proposal. Bruegelpolicybrief, 2010/03, 1-8. Retrieved from http://bruegel.org/2010/05/the-blue-bond-proposal/

Draghi, M. \& Constâncio, V. (2011, March 8). Introductory statement to the press conference (with Q\&A). Retrieved from https://www.ecb.europa.eu/press/pressconf/2011/html/is111208. en.html

Draghi, M. \& Constâncio, V. (2012, September 6). Introductory statement to the press conference (with Q\&A). Retrieved from https://www.ecb.europa.eu/press/pressconf/2012/html/is120906. en.html

Ehrmann, M. \& Fratzscher, M., (2015). Euro Area Government Bonds-Integration and Fragmentation During the Sovereign Debt Crisis. (Working Paper / Document de Travail No. 2015-13) Bank of Canada, Toronto.

European Central Bank ECB, (2010). Decision of the ECB of 14 May 2010 establishing a securities markets programme. Oficial Journal of the European Union (ECB/2010/5). Retrieved from http://data.europa.eu/eli/dec/2010/281/oj

European Commission (2011, November 23). European Commission Green Paper on the feasibility of introducing Stability Bonds. (MEMO/11/820). Retrieved from http://europa.eu/rapid/pressrelease_MEMO-11-820_en.htm

European Commission (2014). Expert Group on Debt Redemption Fund and Eurobills. (Final Report submitted on 31 March 2014). Retrieved from http://ec.europa.eu/economy_finance/ articles/governance/pdf/20140331_conclusion_en.pdf

European Commission. (2018). The 2018 Stability and Convergence Programmes: An Overview and Implications for the Euro Area Fiscal Stance (Institutional Paper No. 088). https://doi. org/10.2765/064898

European Council, (2011). Statement by the Euro Area Heads of State or Government. Retrieved from https://www.cvce.eu/en/obj/statement_by_the_heads_of_state_or_government_of_the_ euro_area_and_eu_institutions_21_july_2011-en-7635d866-ed56-4d4a-94b6-d98f63caeccd. html

German Council of Economic Experts (2011). Verantwortung für Europa wahrnehmen. (Jahresgutachten 2011/12) Sachverständigenrat. Retrieved from https://www. sachverstaendigenrat-wirtschaft.de/publikationen/jahresgutachten/frueherejahresgutachten/jahresgutachten-201112.html

Hellwig, C., \& Philippon, T. (2011, December 2). Eurobills, not Eurobonds. Retrieved from https:// voxeu.org/article/eurobills-not-euro-bonds

Polito, V., \& Wickens, M. (2011). Assessing the fiscal stance in the European Union and the United States, 1970-2011. Economic Policy, 26(68), 599-647. https://doi.org/10.1111/j.14680327.2011.00270.x

Reinhart, C., \& Rogoff, K. (2010). From Financial Crash to Debt Crisis (No. w15795). Cambridge, MA: National Bureau of Economic Research. https://doi.org/10.3386/w15795 
Zettelmeyer, J., Trebesch, C., \& Gulati, M. (2013). The Greek debt restructuring: an autopsy (Working paper WP 13-8) Peterson Institute for International Economics, Massachuetts. Retrieved from https://piie.com/publications/working-papers/greek-debt-restructuringautopsy

APPENDIX FIGURE 1

PUBLIC DEBT-TO-GDP RATIO FOR INDIVIDUAL EA MEMBERS

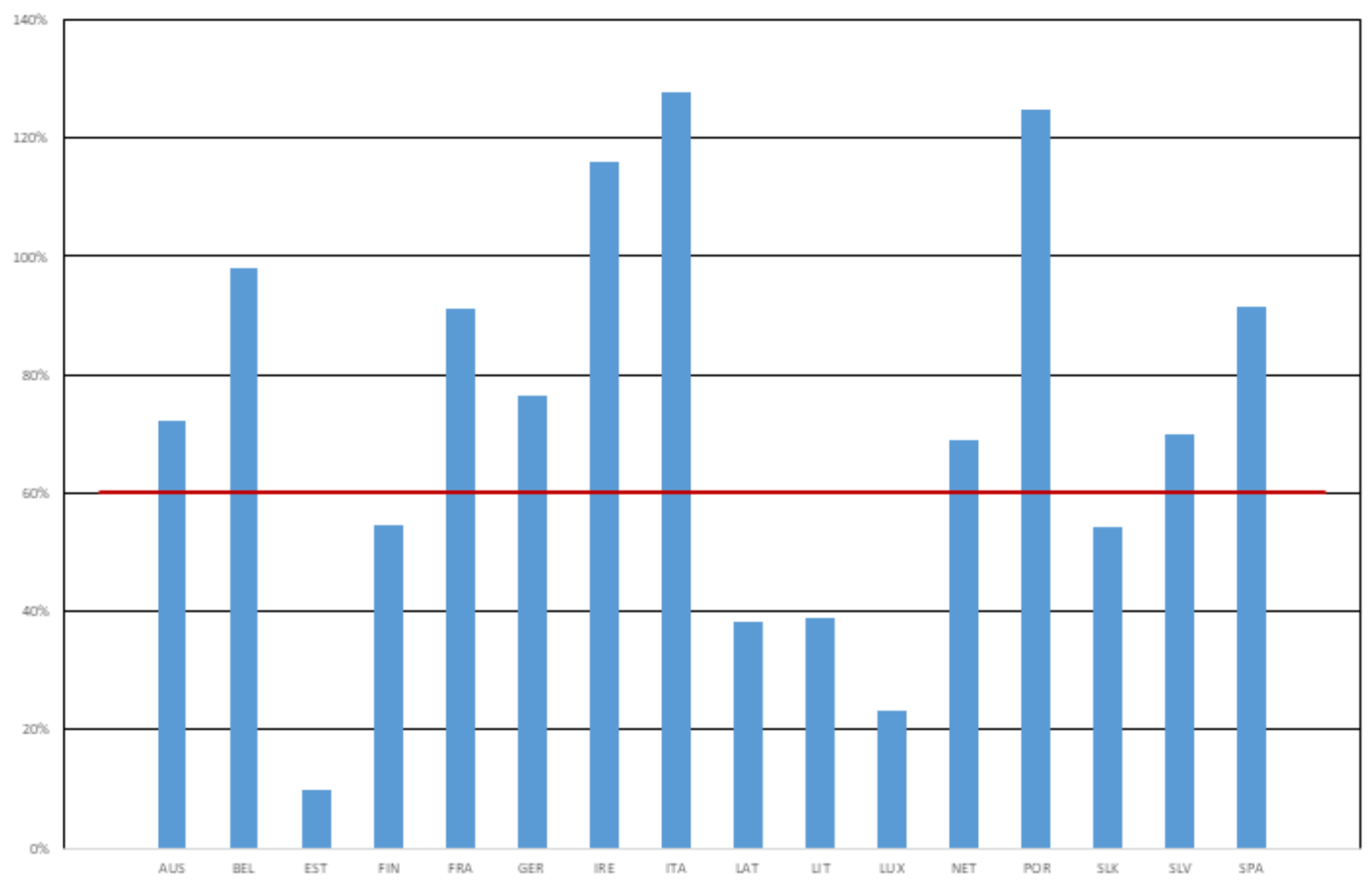


APPENDIX FIGURE 2

PUBLIC DEBT-TO-GDP RATIO FOR COUNTRIES OUTSIDE THE EA AND AGGREGATES

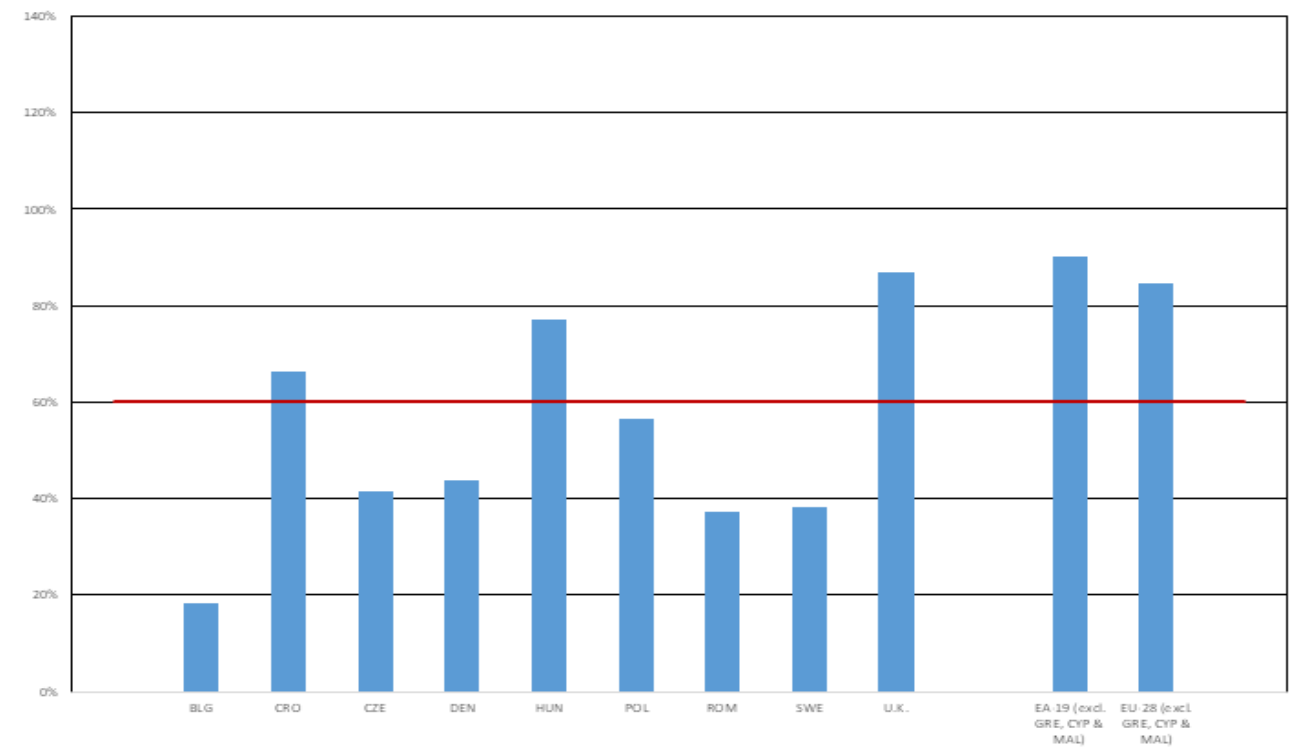

